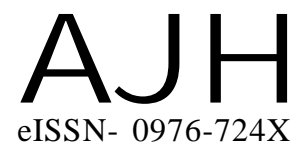

Received : 30.07 .2017

Revised : 04.11.2017

Accepted : 11.11.2017

Members of the Research Forum

Associated Authors:

${ }^{1}$ Krishi Vigyan Kendra

(Dr. P.D.K.V.), YAVATMAL

(M.S.) INDIA
Author for correspondence : JAYASHRI D. UGHADE

Vasantrao Naik College of Agricultural Biotechnology (Dr. P.D.K.V.) YAVATMAL (M.S.) INDIA
THEASIAN JOURNALOF HORTICULTURE

Volume 12 | Issue 2 | December, 2017 | 193-197

Visit us -www.researchjournal.co.in

\title{
Effect of integrated weed management on growth, yield and economic returns on onion (Allium cepa L.)
}

ANJALI M. GAHARWAR ${ }^{1}$, NILIMA PATIL ${ }^{1}$ AND JAYASHRI D. UGHADE

ABSTRACT : A field experiment on integrated weed management was conducted during the Rabi season of 2015-16 at the farm of KVK, Yavatmal. The experiment was conducted in Randomized Block Design with six treatments and four replications. Treatments comprised of $\mathrm{T}_{1}$ - One hand weeding at 20 days after planting of seedlings, $\mathrm{T}_{2}-$ Two hand weedings at 20 and 40 DAT, $\mathrm{T}_{3}$ - Three hand weeding at 20, 40 and 60 DAT, $\mathrm{T}_{4}-$ Spraying of herbicide oxyfluorfen $23.5 \%$ EC 0.1-0.15 kg a.i./ha 15-20 DAT + 1HW at 45 DAT, $\mathrm{T}_{5}-$ Spraying Oxyfluorfen $23.5 \% \mathrm{EC}$ 0.1-0.15 kg a.i./ha before planting $+1 \mathrm{HW}$ at 40-60 DAT and $\mathrm{T}_{6}$ - Control check i.e. without weed control practices. The experiment was carried out in order to evaluate best weed management practices in situation of limited weedicide registered in label claim. The observations on effect of IWM practices on weed parameters, crop growth, bulbs yield were recorded. Minimum weed count and dry matter of weed at 90 DAT with highest weed control efficiency was recorded by the treatment $\mathrm{T}_{4}$ - where spraying of herbicide oxyfluorfen $23.5 \%$ EC $0.1-0.15 \mathrm{~kg}$ a.i./ha $15-20$ DAT $+1 \mathrm{HW}$ at 45 DAT. Regarding the plant growth and bulb yield parameters, the treatment $\mathrm{T}_{4}$ - where spraying of herbicide oxyfluorfen $23.5 \%$ EC $0.1-0.15 \mathrm{~kg}$ a.i./ha $15-20 \mathrm{DAT}+1 \mathrm{HW}$ at 45 DAT was found significantly superior over all the treatments as recorded maximum plant height, neck thickness, dry matter weight of plant, bulb diameter, fresh weight of bulb, cured weight of bulb, bulb yield per plot and per ha. Treatment $\mathrm{T}_{4}$ obtained maximum yield and thereby recorded highest gross return as well as net return and scored highest cost benefit ratio 1:2.09. However, treatment $\mathrm{T}_{5}$ - Spraying Oxyfluorfen $23.5 \%$ EC $0.1-0.15 \mathrm{~kg}$ a.i./ha before planting $+1 \mathrm{HW}$ at $40-60$ DAT ranked second in control of weed growth and gained the higher bulb yield with monetary returns.

KEY WORDS : IWM, Onion, Weed, Oxyfluorfen, Hand weeding, Yield

HOW TO CITE THIS ARTICLE : Gaharwar, Anjali M., Patil, Nilima and Ughade, Jayashri D. (2017). Effect of integrated weed management on growth, yield and economic returns on onion (Allium cepa L.). Asian J. Hort., 12(2) : 193-197, DOI : 10.15740/HAS/TAJH/12.2/193-197. 